\title{
The retinol acid receptor $B$ gene is hypermethylated in patients with familial partial lipodystrophy
}

\author{
Rene Cortese, Florian Eckhardt, Marianne Volleth ${ }^{1}$, Manfred Wehnert ${ }^{2}$, Uwe Koelsch ${ }^{3}$, \\ Peter Wieacker ${ }^{1}$ and Thomas Brune ${ }^{3}$ \\ Epigenomics AG Berlin, Kleine Präsidentenstr. 1, 10178 Berlin, Germany \\ ${ }^{1}$ Institute of Human Genetics, Otto-von-Guericke University, Leipziger Str. 44, 39120 Magdeburg, Germany \\ ${ }^{2}$ Institute for Human Genetics, Ernst-Moritz-Arndt University, Fleischmannstrasse 42/44, 17489 Greifswald, Germany \\ ${ }^{3}$ University Children's Hospital, Department of Perinatology: Gerhard-Hauptmann-Str. 35, 39108 Magdeburg, Germany \\ (Requests for offprints should be addressed to T Brune who is now at Universitätsklinikum Magdeburg, Zentrum für Kinderheilkunde, Gerhard-Hauptmann-Str. 35, D-39108 \\ Magdeburg, Germany; Email: thomas.brune@med.ovgu.de) \\ (R Cortese and F Eckhardt contributed equally to this work)
}

\begin{abstract}
Mutations in the LMNA gene cause various phenotypes including partial lipodystrophy, muscular dystrophies, and progeroid syndromes. The specific mutation position within the $L M N A$ sequence can partially predict the phenotype, but the underlying mechanisms for the development of these different phenotypes are still unclear. To investigate whether different DNA methylation patterns contribute to the development of different phenotypes caused by LMNA mutations, we analyzed a panel of ten candidate genes related to fat metabolism, aging, and a tendency to different methylation patterns: CSPG2, ESR1, IGF1R, IGFR2, LMNA, MLH1, RANBP1, RARB, ZMPSTE24, and TGFBR1. We studied two independent families each comprising three individuals affected by familial partial lipodistrophy type 2 (FPLD2). Affected members in each family carried two different mutations of the LMNA gene (R482L and R471G respectively). In addition, we analyzed four progeria patients $(2 \times$ LMNA/C G608G, $1 \times$ LMNA/C S143F, and $1 \times$ ZMPSTE24 IVS9-Ex10) and seven healthy adults. The gene encoding retinoic acid receptor $\mathrm{B}(R A R B)$ showed a higher methylation in all six patients with FPLD2 when compared with the progeria patients with other $L M N A$ mutations as well as the healthy controls $(P<0 \cdot 05)$. All other investigated genes showed no difference in the methylation patterns between the groups. A drug-induced inhibition of the retinol pathway is discussed as the key pathway for developing HAART-associated lipodystrophy and our data support a possible role of the retinol pathway in the development of lipodystrophy phenotypes.
\end{abstract}

Journal of Molecular Endocrinology (2007) 38, 663-671

\section{Introduction}

Mutations within the $L M N A$ gene cause many diseases with different phenotypes such as different muscular dystrophies, progeroid syndromes, mandibuloacral dysplasia, dilated cardiomyopathies, restrictive dermopathy, and lipodystrophy syndromes. The mutation position within the $L M N A$ sequence can partially predict the phenotype, but the underlying mechanisms for the development of these different phenotypes are still unclear (Hutchison et al. 2001, Hegele 2005). One possible reason could be specific epigenetic alterations of other genes.

Epigenetic alterations such as histone modifications and DNA methylation have been proposed to be involved in the etiology of a number of diseases and to modify their pathological phenotype (Schumacher \& Petronis 2006). Specifically, the best-studied epigenetic modification, DNA methylation, is believed to be involved in human pathologies such as cancer (Baylin 2005), diabetes (Maier \& Olek 2002), atherosclerosis (Dong et al. 2002), inflammatory bowel disease (Kim et al. 1996), inflammatory arthritis (Petronis \& Petroniene 2000), and autoimmune disease (Richardson 2003).

To investigate if different DNA methylation patterns contribute to the development of different phenotypes caused by $L M N A$ mutations, we analyzed a panel of ten candidate genes related to fat metabolism and aging including genes that display an age-dependent differential methylation. We analyzed the selected genes in six familial partial lipodistrophy (FPLD) patients from two independent families and four patients suffering from progeria, all bearing different mutations in the LMNA gene. The results were compared with those offive healthy adults and one healthy member of both FPLD2 families.

\section{Patients, materials and methods}

The Independent Ethics Committee of the University of Magdeburg, Germany, approved the protocol and 
the study was performed according to the guidelines of the Declaration of Helsinki. Written informed consent was obtained from all patients.

\section{Patients}

Ten patients from two independent families bearing different mutations in the LMNA gene were enrolled in the study. Five healthy adults and one healthy member of each of the FPLD2 families served as controls. The patients and the controls were grouped and evaluated as displayed in Table 1.

\section{FPLD group}

Patients 1-3 belong to the same family (Family A) and exhibit the typical phenotype of familial partial lipodistrophy type 2 (FPLD) including acanthosis nigricans, partial lipodystrophy with sparing of the face, severe hypertriglyceridemia, insulin-resistant diabetes, and severe hypertriglyceridemia. Patient 1 is a 36-year-old female and the mother of Patient 2, a 12 -year-old female. Patient 3 is an 8-year-old female and a cousin of patient 2 . All three carry the $L M N A$ mutation
R482L (Ambrosch et al. 1996, Capanni et al. 2003). One healthy member of the family, an 11-year-old female cousin of patient 2 with no mutation, serves as a family internal control (Patient 7).

Patients $4-6$ belong to the same family (Family B) and carry the LMNAR471G mutation. Patient 4, a 14-year-old girl, is affected by an overlapping syndrome including partial lipodystrophy, insulin-resistant diabetes, acanthosis nigricans, liver steatosis, muscle weakness, and contractures. Patient 5 is her 18-year-old sister and exhibits only a partial lipodystrophy. Patient 6 is their father carrying the same mutation but he does not show a lipodystrophy phenotype. Their healthy mother (Patient 12) shows no LMNA mutation and serves as a family internal control (Muschke et al. in press).

\section{Progeria group}

Patients 7 and 8 are a 1-year-old girl and a 5-year-old boy, both affected by typical symptoms of a Hutchinson-Gilford syndrome (progeria) reported by de Busk (1972). Both carry the LMNA G608G mutation typical of progeria (Eriksson et al. 2003, De SandreGiovannoli et al. 2003). Patient 9 is a 5-year-old girl

Table 1 List of all investigated patients and the controls

\begin{tabular}{|c|c|c|c|c|c|c|}
\hline & $\begin{array}{l}\text { Patient } \\
\text { number }\end{array}$ & Sex & $\begin{array}{l}\text { Age } \\
\text { (years) }\end{array}$ & Phenotype & $\begin{array}{l}\text { Lamin } \\
\text { mutation }\end{array}$ & $\begin{array}{l}\text { Additional } \\
\text { mutation }\end{array}$ \\
\hline \multirow[t]{6}{*}{ FPLD group } & Patient 1 & Female & 36 & Familial partial lypodistrophy & $\begin{array}{l}\text { LMNA A/C } \\
\text { R482L }\end{array}$ & None \\
\hline & Patient 2 & Female & 12 & Familial partial lypodistrophy & $\begin{array}{l}\text { LMNA A/C } \\
\text { R482L }\end{array}$ & None \\
\hline & Patient 3 & Female & 8 & Familial partial lypodistrophy & $\begin{array}{l}\text { LMNA A/C } \\
\text { R482L }\end{array}$ & None \\
\hline & Patient 4 & Female & 14 & Familial partial lypodistrophy & $\begin{array}{l}\text { LMNA A/C } \\
\text { R471G }\end{array}$ & None \\
\hline & Patient 5 & Female & 18 & $\begin{array}{l}\text { Familial partial lypodistrophy, } \\
\text { mild phenotype }\end{array}$ & $\begin{array}{l}\text { LMNA A/C } \\
\text { R471G }\end{array}$ & None \\
\hline & Patient 6 & Male & 46 & No phenotype & $\begin{array}{l}\text { LMNA } \\
\text { A/C R471G }\end{array}$ & None \\
\hline \multirow[t]{4}{*}{$\begin{array}{l}\text { Laminopathies } \\
\text { group }\end{array}$} & Patient 7 & Female & 1 & Hutchinson-Gilford syndrome & $\begin{array}{l}\text { LMNA A/C } \\
\text { G608G }\end{array}$ & None \\
\hline & Patient 8 & Male & 7 & Hutchinson-Gilford syndrome & $\begin{array}{l}\text { LMNA A/C } \\
\text { G608G }\end{array}$ & None \\
\hline & Patient 9 & Female & 5 & $\begin{array}{l}\text { Early onset myopathy with } \\
\text { progeria like symptoms }\end{array}$ & $\begin{array}{l}\text { LMNA A/C } \\
\text { S143F }\end{array}$ & None \\
\hline & Patient 10 & Male & 3 & $\begin{array}{l}\text { Progeria-like symptoms, } \\
\text { myopathy, and cardio } \\
\text { myopathy were absent }\end{array}$ & $\begin{array}{l}\text { LMNA A/C } \\
\text { R654X }\end{array}$ & $\begin{array}{l}\text { ZMPSTE24 } \\
\text { IVS9-Ex10 }\end{array}$ \\
\hline \multirow{7}{*}{$\begin{array}{l}\text { Healthy control } \\
\text { group }\end{array}$} & Patient 11 & Female & 11 & Healthy family control & None & None \\
\hline & Patient 12 & Female & 42 & Healthy family control & None & None \\
\hline & Patient 13 & Female & 30 & Healthy control & None & None \\
\hline & Patient 14 & Female & 32 & Healthy control & None & None \\
\hline & Patient 15 & Female & 29 & Healthy control & None & None \\
\hline & Patient 16 & Female & 33 & Healthy control & None & None \\
\hline & Patient 17 & Female & 24 & Healthy control & None & None \\
\hline
\end{tabular}


with an overlapping syndrome including early onset myopathy with progeroid features. She carries a de novo heterozygous LMNA mutation (S143F) and during the first year of life displayed myopathy with marked axial weakness; progeroid features including growth failure, scleroderma-like skin, and osteolytic lesions developed later (Kirschner et al. 2005). Patient 10 is a three and a half-year-old boy suffering from scleroderma-like lesions of the skin which emerged at 3 months of age. Poor weight gain with loss of subcutaneous fat, prominent scalp veins, progressive hair loss, and lentigo senilis were noted shortly afterwards. X-rays revealed the absence of the lateral regions of clavicles as well as acroosteolysis of the fingers, myopathy, and cardiomyopathy. Sequencing of $L M N A$ gene revealed a heterozygous stop mutation leading to a protein which is elongated by seven additional amino acids at the $\mathrm{C}$ terminal. The mother and a healthy brother of the patient carry the same mutation. Sequencing of the ZMPSTE24 gene showed a homozygous deletion of an acceptor splice site (IVS9-Ex10) leading to the complete loss of function of the mutated ZMPSTE24 (Denecke et al. 2006).

\section{Control group}

Five healthy females (Patients 13-17) served as controls.

\section{Lymphoblastoid B-cell lines}

Ten milliliters of venous blood was drawn from each patient and controls, and placed in a heparin blood collection tube. The blood samples were fractionated by the standard Ficoll-Hypaque method (Ficoll Biocoll,
$1.077 \mathrm{~g} / \mathrm{ml}$ Nycomed Pharma AS, Oslo, Norway, Biochrom AG, Berlin, Germany). After washing twice with phosphate buffered saline (PBS), the cells were infected with Epstein-Barr virus (EBV) containing supernatant. After $30 \mathrm{~min}$, culture medium (RPMI 1640) supplemented with $12 \%$ fetal bovine serum (FBS) containing cyclosporin A was added. Six to eight weeks after settingup, an aliquot of the cells was used for further investigations. To rule out an impact of the immortalization process on the methylation pattern of the investigated genes, we compared DNA from freshly prepared lymphocytes (A) and the corresponding immortalized lymphocytes (B) of three healthy probands.

\section{Cryopreservation}

After washing once with serum-free culture medium, the cells were resuspended in cryomedium, i.e. complete culture medium containing 10\% DMSO, transferred to cryotubes, and deposited in a Nalgene Cryo $1{ }^{\circ} \mathrm{C}$ freezing container at $-80{ }^{\circ} \mathrm{C}$ for $24 \mathrm{~h}$. The next day, cryotubes were transferred to a liquid nitrogen container.

\section{Thawing}

The cryotubes were placed in a $37^{\circ} \mathrm{C}$ water bath until the cell suspension was thawed. After washing once with culture medium, the cells were transferred to a culture vessel containing fresh culture medium.

\section{DNA preparation}

DNA was isolated from B-lymphoblastoid cells. Cells were pelleted by centrifugation, washed twice in $1 \times$ PBS

Table 2 Panel of the analyzed genes related to differential methylation, aging, and progeria selected from the literature

\section{Genes full name}

Corresponding reference

\begin{tabular}{|c|c|c|}
\hline \multicolumn{3}{|c|}{ Genes selected due to their age-associated differential methylation } \\
\hline CSPG2 & Versican, chondroitin sulfate proteoglycan core protein 2 & Ahuja et al. (2001) \\
\hline ESR1 & Estrogen receptor 1 & Li et al. (2004) \\
\hline IGF2R & Insulin-like growth factor II receptor & Yang et al. (2000) \\
\hline \multicolumn{3}{|c|}{ Genes selected due to their association with aging } \\
\hline IGF1R & Insulin-like growth factor I receptor & Liang et al. (2003) \\
\hline LMNA & Lamin $A / C$ & Mattout et al. (2006) \\
\hline MLH1 & Homolog of Escherichia coli MutL & Kim et al. (2006) \\
\hline \multicolumn{3}{|c|}{ Genes selected due to their association with progeria } \\
\hline LMNA & Lamin $A / C$ & Mattout et al. (2006) \\
\hline ZMPSTE24 & Zinc metalloprotease STE24 & Denecke et al. (2006) \\
\hline TGFBR1 & Transforming growth factor- $\beta$ receptor, type I & $\begin{array}{l}\text { There are some unpublished reports that transforming } \\
\text { growth factor B in the therapy of children suffering from } \\
\text { Hutchinson-Gilford syndrome is able to slow the } \\
\text { occurrence of symptoms and delay their life span }\end{array}$ \\
\hline
\end{tabular}


and resuspended in $2 \mathrm{ml}$ OLD-T buffer $(40 \mathrm{mM}$ Tris$\mathrm{HCl}, 150 \mathrm{mM} \mathrm{NaCl}, 25 \mathrm{mM}$ EDTA, pH 7.5). After addition of $50 \mu \mathrm{l}$ proteinase $\mathrm{K}$ and $100 \mu \mathrm{l} 20 \%$ SDS, incubation was carried out at room temperature overnight, followed by phenol/chloroform extraction. The DNA was precipitated using two volumes of absolute ethanol.

\section{Candidate genes}

The panel of the analyzed genes consisted of ten candidate genes related to differential methylation, aging and progeria selected from the literature. All genes and the corresponding references are shown in Table 2.

\section{Bisulfite sequencing and evaluation}

The described methods and algorithms have been published previously (Lewin et al. 2004, Rakyan et al. 2004, Eckhardt et al. 2006). The entire workflow is shown in Fig. 1. Bisulfite conversion of genomic DNA was performed as previously described, followed by a direct quantification of DNA methylation. Briefly, the bisulfite reaction was carried out using genomic DNA that was treated with a $2.5 \mathrm{M}$ sodium bisulfite solution (Berlin et al. 2005), converting unmethylated cytosines into uracil, whereas methylated cytosines remained unaltered. Upon PCR amplification, the uracil was converted into a thymine and the cytosine:thymine ratio was used for the methylation quantification as described below. PCR amplification using primers (Table 3) flanking the region of interest was performed with Qiagen hot-start PCR reagents using the following PCR profile: hot-start at $95^{\circ} \mathrm{C}$ for $15 \mathrm{~min}\left(95^{\circ} \mathrm{C}\right.$ for $1 \mathrm{~min}, 55^{\circ} \mathrm{C}$ for $45 \mathrm{~s}, 72^{\circ} \mathrm{C}$ for $\left.1 \mathrm{~min}\right) \times 40$ cycles, and an elongation step of $72{ }^{\circ} \mathrm{C}$ for $10 \mathrm{~min}$. PCR amplicons were controlled by agarose gel electrophoresis, and excess nucleotides and primers were subsequently removed using ExoSAP-IT (USB Corporation, Cleveland, OH, USA).

The PCR product (without prior subcloning) was subsequently sequenced on an ABI 3730 capillary sequencer using the same PCR primers and a $1 / 20$ dilution of the ABI Prism Big Dye terminator V3.1 kit (Applied Biosystems, Foster City, CA, USA). The sequencing thermo profile included an initial incubation at $96{ }^{\circ} \mathrm{C}$ for $120 \mathrm{~s}$ followed by 25 thermo cycles $\left(96{ }^{\circ} \mathrm{C}\right.$ for $30 \mathrm{~s}, 55^{\circ} \mathrm{C}$ for $15 \mathrm{~s}, 60^{\circ} \mathrm{C}$ for $\left.240 \mathrm{~s}\right)$.

Quantitative cytosine methylation levels were calculated from the ABI sequencing trace files as previously described (Lewin et al. 2004, Rakyan et al. 2004, Eckhardt et al. 2006). In brief, after trace curve normalization, the methylation of each individual cytosine-phosphate-guanine site $(\mathrm{CpG})$ was quantified

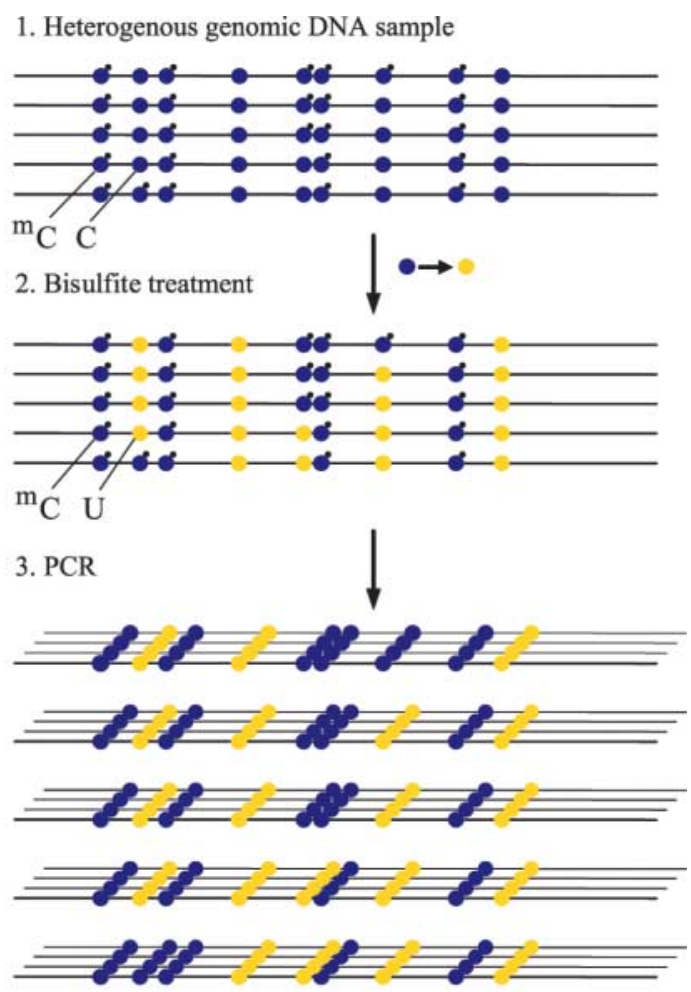

4. Sequencing
5. Trace file analysis

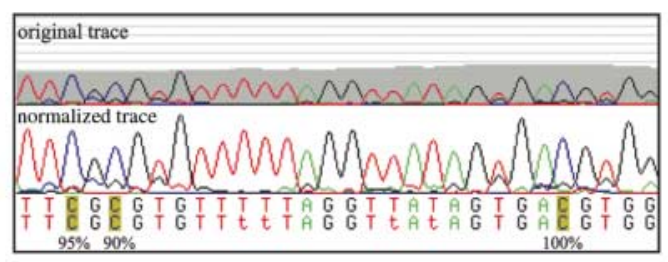

6. Methylation quantification

6. Statistical analysis

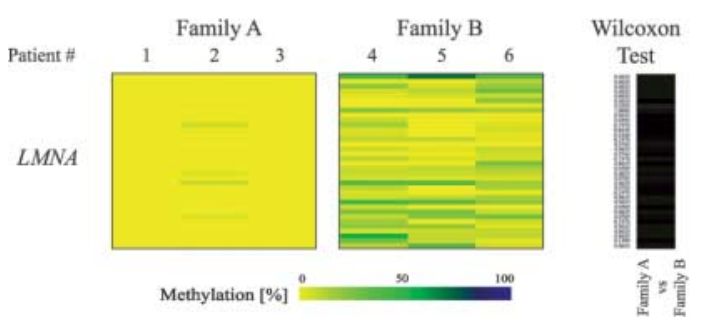

Figure 1 Workflow of bisulfite sequencing and evaluation of the candidate genes. After the bisulfite treatment, methylation values are calculated from the sequence trace file using the $C: T$ signal intensities. Methylation values for each sample and CpG position are color coded ranging from $0 \%$ methylation (yellow) to $100 \%$ methylation (blue). 
Table 3 Primers used for PCR amplification

\begin{tabular}{|c|c|c|c|c|}
\hline & Location $^{\mathrm{a}}$ & Primer 1 sequence & Primer 2 sequence & Fragment length \\
\hline \multicolumn{5}{|l|}{ Gene symbol } \\
\hline IGF2R & $5^{\prime}$ UTR & ATAGAAGGTTTGAGAGGTTTTG & СТTСССАААТTААААСААСТАТТС & 207 \\
\hline TGFBR1 & $5^{\prime}$ UTR & GGAGGAAATAGGAGAGTGAGT & АААТСТАССААССССААСА & 345 \\
\hline LMNA & Exon 1 & GTTGTAGGAGAAGGAGGATTTG & TCCCAAAAACCACCACTT & 486 \\
\hline CSPG2 & $5^{\prime}$ UTR & GTGGGGAATATGTAAGGAAA & СССАAACAACСТАAAACСТTА & 460 \\
\hline$h M L H 1$ & $5^{\prime}$ UTR & ATTGATTGGATAGTTTGAATGTT & CСAAATCACCTCAACAAAAA & 240 \\
\hline IGF1R & Intron 1 & TTATTGGTATATTTAAGATGGTAGGG & AAAAATAAAAACCCTCСТTTATC & 478 \\
\hline ZMPSTE24 & Exon 1 & GGAGGGATTAGGGAGAGTTT & ССТССТСААААССАСААТС & 495 \\
\hline$R A N B P 1$ & $5^{\prime}$ UTR & TTAAAGTGGTTGGGGGTT & TCСССАССТАТTСТСТАACA & 492 \\
\hline ESR1 & $5^{\prime}$ UTR & TTGTTGGATAGAGGTTGAGTTT & СТATCAATTCССССAACTACT & 349 \\
\hline$R A R B$ & Intron 1 & GTTGTTTAGAGGTAGGAGGGTT & ACAATCAAACATAATCTCCCTT & 458 \\
\hline
\end{tabular}

$\mathrm{a}_{5^{\prime}}$ UTR, $5^{\prime}$-untranscribed region.

by $\mathrm{C}: \mathrm{T}$ signal peak intensities ratios at the cytosine position located within a CpG (the dinucleotide where DNA cytosine methylation occurs). Only sequences displaying a conversion rate higher than $98 \%$ were used for analysis. Methylation values for individual Cs within each amplicon and sample were calculated and visualized by color coding ranging from dark blue ( $100 \%$ methylation) to yellow ( $0 \%$ methylation). The rows of the matrix correspond to the methylation levels of individual CpG sites, and each column represents an individual sample.

To minimize the risk of possible methylation variation caused by the immortalization process, our cell culture methodology or the freezing and thawing process (Liu et al. 2005), we compared the methylation pattern DNA from freshly prepared lymphocytes and the corresponding immortalized lymphocytes before and after thawing of three healthy probands.

\section{Statistical analysis}

Differential methylation was tested for significance using Wilcoxon's rank sum test. Significant results $(P<0 \cdot 05)$ were visualized as a green box on the right of the figures.

\section{Results}

Figure 2 displays the methylation profiles of all individuals investigated beside the two healthy family controls. In all 14 samples, the ten genes analyzed showed a low methylation level of $0-30 \%$. Within the FPLD group, the RARB gene showed a significantly higher methylation $(P<0 \cdot 05)$ in all six patients when compared with both patients with other $L M N A / C$ mutations and to healthy controls. In addition, we observed methylation differences between the two families in the FLPD group with, for example, LMNA being highly methylated in patients 1-3 (Family A) than in patients 4-6 (Family B). However, these findings were not statistically significant when tested against the control group or the progeria group.

The methylation profile of the $R A R B$ gene is shown in detail in Fig. 2b. The figure shows that the healthy members of each affected FPLD family also displayed a significantly lower methylation of the $R A R B$ gene when compared with the affected family members. No difference in methylation could be detected between the healthy members of the FPLD family, the progeria patients, and unrelated healthy controls.

Noteworthy, all methylation changes were detected in B-lymphoblastoid cells isolated from whole blood samples. This fact enables the study with minimal intervention, which is a very desirable feature in a diagnostic procedure. In order to control possible changes in the methylation patterns introduced during culture and freezing-thawing of the cells (Liu et al. 2005), we compared DNA from freshly prepared lymphocytes and the corresponding immortalized lymphocytes of three healthy probands (Fig. 3). The methylation profiles of our marker did not change during the immortalization process or different steps of culture suggesting that the immortalization process had no effect on the methylation pattern of these genes.

\section{Discussion}

FPLD patients have a normal fat distribution in early childhood, but with the onset of puberty, subcutaneous adipose tissue gradually disappears from the upper and lower extremities as well as from the gluteal and truncal regions, resulting in a muscular appearance with prominent superficial veins. Simultaneously, the adipose tissue accumulates on the face and neck, causing a double chin, fat neck, or cushingoid appearance. Adipose tissue may also accumulate in the axillae, back, labia majora, and intra-abdominal region (Kobberling \& Dunnigan 1986). The lipodystrophies 
(a)

Group FPLD Healthy $\quad P$-Value

$\begin{array}{llllllllllllllllll}\text { Patient \# } & 1 & 2 & 3 & 4 & 5 & 6 & 7 & 8 & 9 & 10 & 11 & 12 & 13 & 14 & 15 & 16 & 17\end{array}$

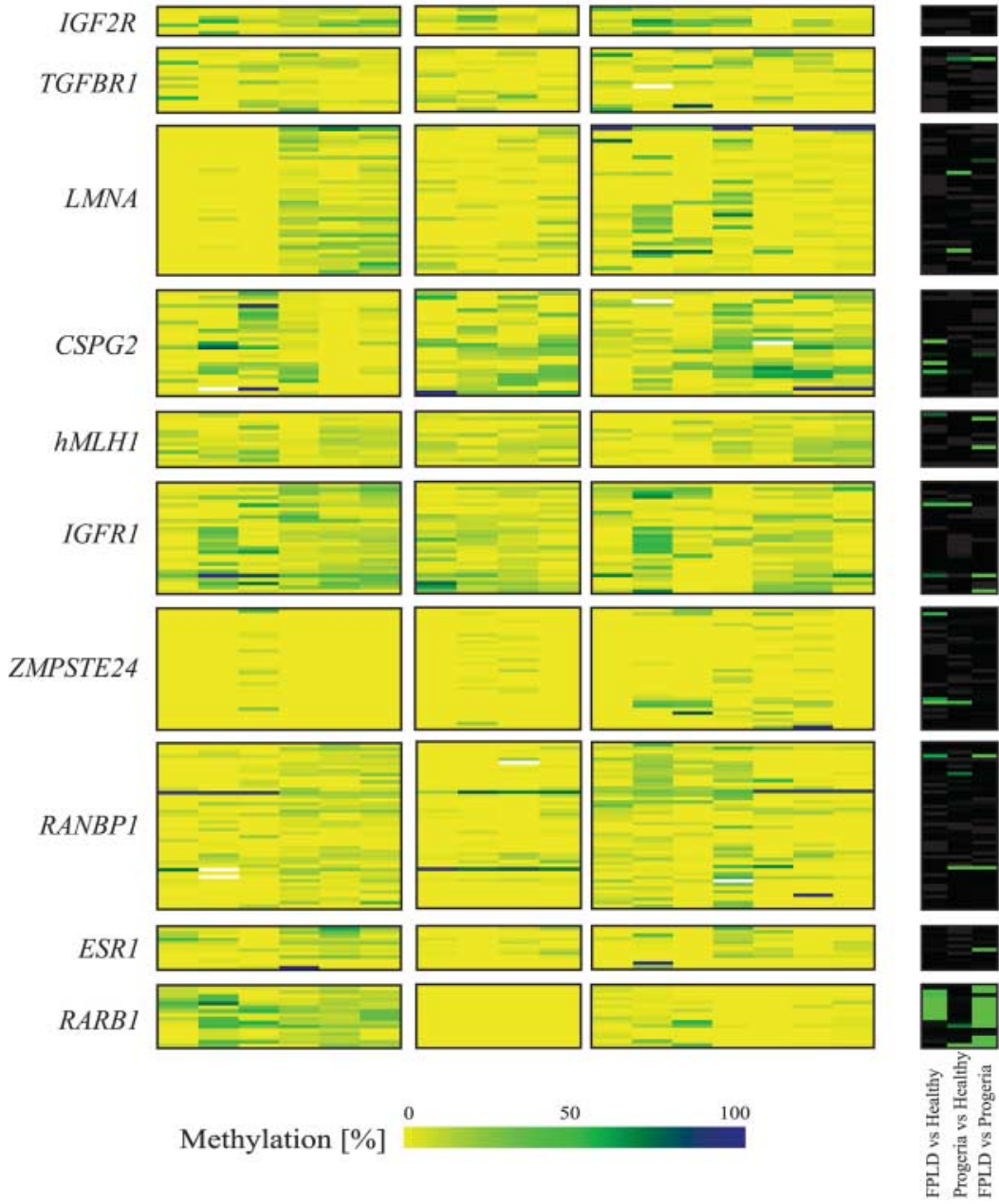

(b)
FPLD
Laminopathies
Healthy

Wilcoxon

$\begin{array}{llllllllllllllllll}\text { Patient \# } & 1 & 2 & 3 & 4 & 5 & 6 & 7 & 8 & 9 & 10 & 11 & 12 & 13 & 14 & 15 & 16 & 17\end{array}$

$R A R B I$
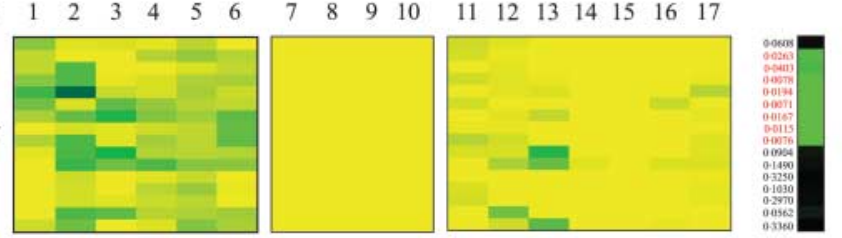

test
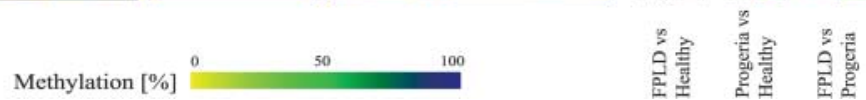

Figure 2 (a) Methylation profiles of all investigated individuals. The ten genes of all samples analyzed showed a low methylation level of $0-30 \%$. The methylation profile of the $R A R B$ gene is shown in detail in (b). The LMNA gene shows a higher methylation level in patients 1-3 (Family A) than in patients 4-6 (Family B). This result is not statistically significant when tested against the control group or the progeria group. (b) The methylation profile of the RARB gene in detail. Within the FPLD group, the RARB gene showed a significantly higher methylation $(P<0.05)$ in all six patients when compared with both patients with other $L M N A / C$ mutations and when compared with healthy controls. 


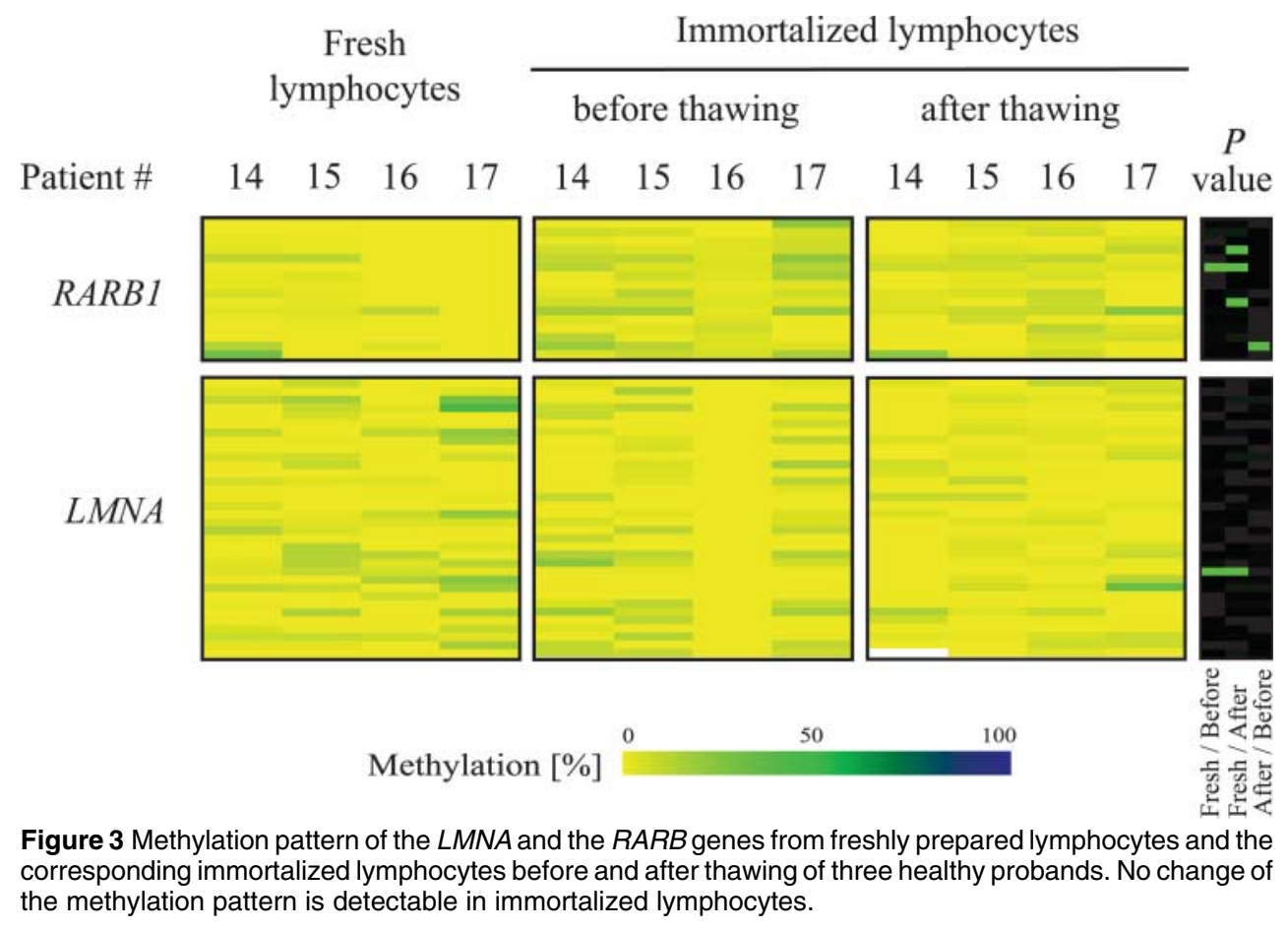

are familial or acquired disorders characterized by variable loss of fat tissue. In FPLD, loss of fat occurs during puberty. In a subgroup of FPLD, Dunnigan type or FPLD2, subcutaneous fat is lost from the limbs and partially from the trunk. Later on, the patients may show acanthosis nigricans, hirsutism, polycystic ovaries, insulin-resistant diabetes, dyslipidemia, and liver steatosis. Although FPDL2 is caused by mutations of LMNA (Hegele et al. 2000a,b,c), its manifestation is markedly dependent on sex with female carriers more severely affected (Vigouroux et al. 2000). This may indicate that epigenetic factors also play a role in the development of the lipodystrophic phenotype.

In the present study, we investigated the relation of DNA methylation and the underlying mutation as a reason for the development of the differential phenotypes in patients bearing LMNA mutations. For this purpose, we analyzed the methylation patterns of ten candidate genes in patients with FPLD2, with other laminopathies and controls. Out of the ten gene methylation profiles, we found that the studied amplicon of the $R A R B$ gene is significantly hypermethylated in FLPD when compared with the patients with other laminopathies, indicating an epigenetic component in this disease. The studied amplicon is located in intron 1 of the annotated $R A R B$ gene (Ensembl v42).

The $R A R B$ gene encodes the RAR- $\beta$ and mediates retinoid effects in controlling cell growth, differentiation, apoptosis, and carcinogenesis. $R A R B$ has been shown to be differentially methylated in several cancers
(Paz et al. 2003) such as malignant melanoma (Furuta et al. 2004), testicular tumors (Kawakami et al. 2003), and carcinoma of cervix (Narayan et al. 2003). Although the function of RARB in the etiology of FLPD2 is currently not known, it is noteworthy that protease inhibitor therapy of human immunodeficiency virus (HIV) is frequently associated with a FPLD-like condition characterized by lipoatrophy of the limbs, fat accumulation of abdomen, breasts and cervical region ('buffalo hump'), hyperlipidemia, and insulin resistance. This symptoms complex is called highly active anti-retroviral therapy (HAART)-related lipodystrophy syndrome (Carr 2000). Protease inhibitors including indinavir have been shown to reduce adipocyte cell differentiation and increase apoptosis of adipocytes in vitro. The HAART-related lipodystrophy syndrome may be a result of the inhibition of two proteins involved in lipid metabolism, which have significant homology to the catalytic site of HIV protease, namely cytoplasmic retinoic acid-binding protein (cRABP) and low-density lipoprotein receptorrelated protein (Lenhard et al. 2000). CRABP is an intracellular protein involved in the transmission of the vitamin A-derived signal, which regulates genes responsible for lipid metabolism and adipocyte differentiation (Carr et al. 1998).

Although the phenotypes of HAART-induced lipodystrophy and FPLD seem distinct in the sense that FLDP patients have fat deposition in face and neck whereas HAART lipodystrophic individuals have facial fat loss, 
both the phenotypes have multiple clinical and metabolic features in common (Behrens et al. 2000). Our results and the above-mentioned role concerning the inhibition of CRABP in the etiology of HAARTrelated lipodystrophy suggest a link between the retinoic acid pathway and lipodystrophy phenotypes and support a role for changes in the methylation of the retinoic acid receptor gene in the development of lypodystrophic phenotypes.

The different DNA methylation of the LMNA gene between the two FPLD families may play an additional role in the different development of the FPLD phenotype. Although the difference in $L M N A$ is visible in the plot, the $P$ values after the Wilcoxon's test do not show statistical significance. As we compared only three patients in each group, marginal $P$ values are expected. Thus, these results would suggest a trend towards differential methylation of LMNA gene between both families carrying different mutations. Additional studies focusing on the link between the observed differential methylation and the different mutation in LMNA will allow an understanding of whether they have a synergetic effect on the development of the phenotype.

\section{Acknowledgements}

$\mathrm{R} \mathrm{G}$ is an employee of Epigenomics AG. F E was an employee of Epigenomics AG during the study. The authors declare that there is no conflict of interest that would prejudice the impartiality of this scientific work.

\section{References}

Ahuja N, Toyota M, Bronner MP \& Brentnall TA 2001 Accelerated agerelated CpG island methylation in ulcerative colitis Issa JP. Cancer Research 61 3573-3577.

Ambrosch A, Mohnike K \& Luley C 1996 Severe generalized lipodystrophy type A can be effectively improved by lipid lowering. Experimental and Clinical Endocrinology and Diabetes 104 97A.

Baylin SB 2005 DNA methylation and gene silencing in cancer. Nature Clinical Practice, Oncology 2 S4-S11.

Behrens GM, Lloyd D, Schmidt HH, Schmidt RE \& Trembath RC 2000 Lessons from lipodystrophy: LMNA, encoding lamin A/C, in HIV therapy-associated lipodystrophy. AIDS 14 1854-1855.

Berlin K, Ballhause M \& Cardon K 2005 Improved bisulfite conversion of DNA. Patent PCT/WO/2005/038051.

de Busk FL 1972 The Hutchinson-Gilford progeria syndrome. Journal of Pediatrics 80 697-794.

Capanni C, Cenni V, Mattioli E, Sabatelli P, Ognibene A, Columbaro M, Parnaik VK, Wehnert M, Maraldi NM, Squarzoni S et al. 2003 Failure of lamin A/C to functionally assemble in R482L mutated familial partial lipodystrophy fibroblasts: altered intermolecular interaction with emerin and implications for gene transcription. Experimental Cell Research 291 122-134.

Carr A 2000 HIV protease inhibitor-related lipodystrophy syndrome. Clinical Infectious Diseases 30 S135-S142.

Carr A, Samaras K, Chisholm DJ \& Cooper DA 1998 Pathogenesis of HIV-1-protease inhibitor-associated peripheral lipodystrophy, hyperlipidaemia, and insulin resistance. Lancet 351 1881-1883.
Denecke J, Brune T, Feldhaus T, Robenek H, Kranz C, Auchus RJ, Agarwal AK \& Marquardt T 2006 A homozygous ZMPSTE24 null mutation in combination with a heterozygous mutation in the LMNA gene causes Hutchinson-Gilford progeria syndrome (HGPS): insights into the pathophysiology of HGPS. Human Mutation 27 524-531.

De Sandre-Giovannoli A, Bernard R, Cau P, Navarro C, Amiel J, Boccaccio I, Lyonnet S, Stewart CL, Munnich A, Le Merrer M et al. 2003 Lamin a truncation in Hutchinson-Gilford progeria. Science 3002055.

Dong C, Yoon W \& Goldschmidt-Clermont PJ 2002 DNA methylation and atherosclerosis. Journal of Nutrition 132 2406S-2409S.

Eckhardt F, Lewin J, Cortese R, Rakyan VK, Attwood J, Burger M, Burton J, Cox TV, Davies R, Down TA et al. 2006 DNA methylation profiling of human chromosomes 6, 20 and 22. Nature Genetics 38 1378-1385 (Epub 2006 Oct 29).

Eriksson M, Brown WT, Gordon LB, Glynn MW, Singer J, Scott L, Erdos MR, Robbins CM, Moses TY, Berglund P et al. 2003 Recurrent de novo point mutations in lamin A cause Hutchinson-Gilford progeria syndrome. Nature 423 293-298.

Furuta J, Umebayashi Y, Miyamoto K, Kikuchi K, Otsuka F, Sugimura T \& Ushijima T 2004 Promoter methylation profiling of 30 genes in human malignant melanoma. Cancer Science 95 962-968.

Hegele R 2005 LMNA mutation position predicts organ system involvement in laminopathies. Clinical Genetics 68 31-34.

Hegele RA, Cao H, Anderson CM \& Hramiak IM $2000 a$ Heterogeneity of nuclear lamin A mutations in Dunnigan-type familial partial lipodystrophy. Journal of Clinical Endocrinology and Metabolism $\mathbf{8 5}$ 3431-3435.

Hegele RA, Cao H, Huff MW \& Anderson CM 2000 $b$ LMNA R482Q mutation in partial lipodystrophy associated with reduced plasma leptin concentration. Journal of Clinical Endocrinology and Metabolism 85 3089-3093.

Hegele RA, Anderson CM \& Cao H 2000c Lamin A/C mutation in a woman and her two daughters with Dunnigan-type partial lipodystrophy and insulin resistance. Diabetes Care 23 258-259.

Hutchison CJ, Alvarez-Reyes M \& Vaughan OA 2001 Lamins in disease: why do ubiquitously expressed nuclear envelope proteins give rise to tissue-specific disease phenotypes? Journal of Cell Science 114 9-19.

Kawakami T, Okamoto K, Kataoka A, Koizumi S, Iwaki H, Sugihara H, Reeve AE, Ogawa O \& Okada Y 2003 Multipoint methylation analysis indicates a distinctive epigenetic phenotype among testicular germ cell tumors and testicular malignant lymphomas. Genes Chromosomes Cancer 38 97-101.

Kim YI, Logan JW, Mason JB \& Roubenoff RJ 1996 DNA hypomethylation in inflammatory arthritis: reversal with methotrexate. Journal of Laboratory and Clinical Medicine 128 2165-2172.

Kim DJ, Yi SM, Lee SY, Kang HS, Choi YH, Song YW \& Park SC 2006 Association between the $M L H 1$ gene and longevity. Human Genetics 119 353-354.

Kirschner J, Brune T, Wehnert M, Denecke J, Wasner C, Feuer A, Marquardt T, Ketelsen UP, Wieacker P, Bonnemann CG et al. 2005 p.S143F mutation in lamin A/C: a new phenotype combining myopathy and progeria. Annals of Neurology 57 148-151.

Kobberling J \& Dunnigan MG 1986 Familial partial lipodystrophy: two types of an X linked dominant syndrome, lethal in the hemizygous state. Journal of Medical Genetics 23 120-127.

Lenhard JM, Weiel JE, Paulik MA \& Furfine ES 2000 Stimulation of vitamin $\mathrm{A}(1)$ acid signaling by the HIV protease inhibitor indinavir. Biochemical Pharmacology 59 1063-1068.

Lewin J, Schmitt AO, Adorjan P, Hildmann T \& Piepenbrock C 2004 Quantitative DNA methylation analysis based on four-dye trace data from direct sequencing of PCR amplificates. Bioinformatics $\mathbf{2 0}$ 3005-3012.

Li LC, Shiina H, Deguchi M, Zhao H, Okino ST, Kane CJ, Carroll PR, Igawa M \& Dahiya R 2004 Age-dependent methylation of ESR1 gene in prostate cancer. Biochemical and Biophysical Research Communications 321 455-461. 
Liang H, Masoro EJ, Nelson JF, Strong R, McMahan CA \& Richardson A 2003 Genetic mouse models of extended lifespan. Experimental Gerontology 38 1353-1364.

Liu L, Zhang J, Bates S, Li JJ, Peehl DM, Rhim JS \& Pfeifer GP 2005 A methylation profile of in vitro immortalized human cell lines. International Journal of Oncology 26 275-285.

Maier S \& Olek A 2002 Diabetes: a candidate disease for efficient DNA methylation profiling. Journal of Nutrition 132 2440S-2443S.

Mattout A, Dechat T, Adam SA, Goldman RD \& Gruenbaum Y 2006 Nuclear lamins, diseases and aging. Current Opinion in Cell Biology 18 335-341.

Muschke P, Kölsch U, Jakubiczka S, Wieland I, Brune T \& Wieacker P (in press) The heterozygous LMNA/C mutation R471G causes a laminopathy including partial lipodystrophy, insulin-resistant diabetes, liver steatosis, muscle weakness and contractures. Clinical Genetics.

Narayan G, Arias-Pulido H, Koul S, Vargas H, Zhang FF, Villella J, Schneider A, Terry MB, Mansukhani M \& Murty VV 2003 Frequent promoter methylation of $C D H 1, D A P K, R A R B$, and HIC1 genes in carcinoma of cervix uteri: its relationship to clinical outcome. Molecular Cancer 1324.

Paz MF, Fraga MF, Avila S, Guo M, Pollan M, Herman JG \& Esteller M 2003 A systematic profile of DNA methylation in human cancer cell lines. Cancer Research 63 1114-1121.

Petronis A \& Petroniene R 2000 Epigenetics of inflammatory bowel disease. Gut 47 302-306.

Pujol G, Soderqvist H \& Radu A 2002 Age-associated reduction of nuclear protein import in human fibroblasts. Biochemical and Biophysical Research Communications 294 354-358.
Rakyan VK, Hildmann T, Novik KL, Lewin J, Tost J, Cox AV, Andrews TD, Howe KL, Otto T, Olek A et al. 2004 DNA methylation profiling of the human major histocompatibility complex: a pilot study for the human epigenome project. PLoS Biology 2 e405.

Richardson B 2003 DNA methylation and autoimmune disease. Clinical Immunology 109 72-79.

Schumacher A \& Petronis A 2006 Epigenetics of complex diseases: from general theory to laboratory experiments. Current Topics in Microbiology and Immunology 310 81-115.

Si SP, Tsou HC, Lee X \& Peacocke M 1995 Effect of cellular senescence and retinoic acid on the expression of cellular retinoic acid-binding proteins in skin fibroblasts. Experimental Cell Research 219 243-248.

Vigouroux C, Magre J, Vantyghem MC, Bourut C, Lascols O, Shackleton S, Lloyd DJ, Guerci B, Padova G, Valensi P et al. 2000 Lamin $A / C$ gene: sex-determined expression of mutations in Dunnigan-type familial partial lipodystrophy and absence of coding mutations in congenital and acquired generalized lipoatrophy. Diabetes 49 1958-1962.

Yang IC, Yang SK, Park CW \& Chung JH 2000 De novo methylation at intronic CpG islands of Igf2r is associated with decreased expression of antisense RNA in aged mice. Biochemical and Biophysical Research Communications 274 722-726.

Received in final form 4 April 2007

Accepted 12 April 2007

Made available online as an Accepted Preprint 18 April 2007 